Volume 4 • Nomor $1 \cdot$ Oktober 2020

Pege (Hal.) : $52-61$

(C) Universitas Pamulang

JL.Surya Kencana No.1 Pamulang, Tangerang Selatan - Banten

Telp. (021) 7412566, Fax (021) 7412491

website. :

Email : jurnalmarketing.unpam@gmail.com

\title{
Analisis SWOT pada Strategi Bisnis Kompetensi Kepuasan Pelanggan (Study Kasus pada Customer dari PT. Protekindo Sanita, Kab.Tangerang)
}

\author{
Haryantini* \\ *Universitas Pamulang, email ; dosen01640@unpam.ac.id
}

\begin{abstract}
Abstrak. Tujuan dari penelitian ini adalah untuk mengkaji dan menganalisis kekuatan, kelemahan, peluang dan ancaman apa saja yang akan terjadi dari strategi bisnis kompetensi pasar khususnya pada customer dari PT Protekindo Sanita, Permasalahan dalam penelitian ini adalah meningkatnya jumlah permintaan produk hand sanitizer yang disebabkan terjadinya pandemi virus Covid-19 yang mengharuskan memakai hand sanitizer sebagai salah satu upaya mengurangi kasus penyebaran virus Covid-19. Metode penelitian menggunakan metode deskriptif kualitatif. Populasi dalam penelitian ini adalah customer hotel dan restoran yang menggunakan poduk hand sanitizer. Dengan menggunakan teknik sampling, data diperoleh dari hasil wawancara dan dokumentasi. Hasil penelitian diperoleh bahwa proses pemakaian produk hand sanitizer memiliki keunggulan yaitu mudah saat digunakan dan tanpa melalui proses bilas. Adapun terdapat kelemahannya seperti susah didapat dan mulai langka karna bahan baku yang semakin jarang membuat produk ini mengalami peningkatan harga jual. Gaya hidup masyarakat yang selalu bertransaksi online dan akan ada penambahan antar online menjadi peluang pasar dalam peningkatan kualitas layanan produk. Dibalik itu terdapat ancaman pula seperti kualitas produk pesaing yang lebih unggul dan bebas antar.
\end{abstract}

Kata kunci : Analisis SWOT; Covid-19; Hand Sanitizer; Stategi Bisnis.

Abstract.The purpose of this study is to study and analyze the strengths, weaknesses, opportunities and threats that will occur from the business competence market strategy, especially for customers of PT Protekindo Sanita. The problem in this study is the increasing number of hand sanitizer product requests caused by a virus pandemic Covid-19 which requires using hand sanitizer as an effort to reduce the case of the spread of the Covid-19 virus. The research method uses qualitative descriptive methods. The population in this study are hotel and restaurant customers who use hand sanitizer products. By using a sampling technique, data obtained from interviews and documentation. The results showed that the process of using hand sanitizer products has the advantage of being easy when used and without going through the rinse process. As for the weaknesses, such as hard to get and starting to scarce because raw materials are increasingly rare to make this product an increase in selling prices. The lifestyle of people who are always transacting online and there will be an increase between online is a market opportunity in improving the quality of product services. Behind that there are also threats such as the quality of competing products that are superior and free between.

Keywords: SWOT Analysis; Covid-19; Hand Sanitizer; Business Strategy. 


\section{A. PENDAhUluan}

Berbagai penyakit seperti penyakit pernafasan dan penyakit pencernaan disebabkan oleh sistem imun tubuh yang terganggu oleh virus. Widyastuti (2013) menyebutkan virus penyebab infeksi saluran pencernaan seperti bakteri Staphylococcus dan Streptococcus dengan mudah mampu menyerang sistem pencernaan manusia melalui tangan dan udara. Dewasa ini, isu penyebaran virus Covid-19 yang sudah menjadi wabah pandemi dunia dan sudah sampai ke Indonesia. Membuat terjadinya perubahanan perilaku sosial masyarakat yang lebih aktif dan menjadikan mencuci tangan dengan sabun, Handsanitizer atau pembersih tangan antiseptik merupakan suatu hal yang wajib dilakukan untuk menjaga kebersihan tangan. Hal ini menjadi peluang bisnis produk handsanitizer terus meningkat dibuktikan meningkatnya jumlah merek produk tersebut di pasar. Dwianto (2007) mencatat sedikitnya ada tujuh merek handsanitizer yang dijual di pasar yakni Antis, Handy Clean, Nuvo, Number 1, Eskulin, Instance dan Laxmay pada tahun 2001 hingga 2007. Merek-merek yang kini beredar di pasar selain yang disebutkan sebelumnya mengalami penambahan diantaranya Carrex, Dettol, Purrel, Calmic (Pengamatan di Alfamart, Alfamidi, Carrefour, Giant pada tahun 2014) serta handsanitizer tanpa merek yang diimpor dari China dan Korea (pengamatan Online shop 2014).

Mengingat besarnya peluang bisnis tersebut, invensi berupa produk handsanitizer perlu dikomersialisasikan. Dalam mengomersialkan produk, peninjauan mendalam mengenai produk yang akan ditawarkan serta strategi bisnis perlu dilakukan. Peninjauan produk mencakup identifikasi pasar, desain prototipe, riset dan pengembangan serta analisis penerimaan masyarakat. Peninjauan yang diperlukan setelah itu adalah perumusan rencana strategi yang sesuai untuk peluncuran produk. Perumusan strategi bisnis diperlukan guna mengetahui langkah melaksanakan aktivitas bisnis melalui tahapan identifikasi faktor, evaluasi faktor, positioning dan penentuan skenario. Melalui identifikasi kekuatan, kelemahan, peluang dan ancaman yang ada di lingkungan bisnis, manajemen akan peka terhadap faktor keberhasilan peluncuran produk. Evaluasi lanjutan terhadap faktor peluncuran produk akan menghasilkan positioning bisnis dalam menentukan skenario strategi. Rangkaian kegiatan ini perlu dilakukan untuk memperoleh gambaran nyata pengembangan bisnis produk gel handsanitizer. Penelitian ini akan menghasilkan sistem pengembangan bisnis pada produk handsanitizer. Output yang diharapkan dari penelitian ini adalah penerimaan masyarakat terhadap prototipe serta skenario strategi peluncuran produk. Hasil dari penelitian ini diharapkan dapat bermanfaat bagi peneliti yang akan melanjutkan riset terhadap handsanitizer, bagi calon pelaku bisnis handsanitizer serta bagi para pembaca karya ini

\section{B. METODE PENELITIAN}

\section{Waktu dan Tempat Penelitian}

Penelitian ini dilaksanakan mulai tanggal 16 Maret 2020 sampai 30 Maret 2020.

Penelitian ini dilaksanakan di wilayah Jakarta, dan Kab. Tangerang.

\section{Lingkup Penelitian}

Penelitian dilakukan untuk memperoleh data analisis SWOT produk Hand sanitiziter. Kegiatan ini meliputi identifikasi pasar, serta analisis penerimaan pelanggan.

\section{Identifikasi pasar}

Identifikasi pasar dilakukan untuk menentukan segmen pasar dan besarnya pasar yang dituju melalui studi literatur dan observasi calon pelanggan. Observasi 
pelanggan dilakukan dengan metode kuisioner teknik wawancara (Singrimbun dan Sofyan 1987) kepada 50 responden. Jumlah 50 responden untuk mengurangi besarnya standar error dari hasil penghitungan, di mana syarat minimal jumlah responden untuk memenuhi statistik adalah 30 responden.

\section{Analisis penerimaan pelanggan}

Analisis penerimaan pelanggan dilakukan untuk mengetahui pengaruh rangkaian identifikasi pasar hingga kegiatan riset terhadap penerimaan calon pelanggan. Kegiatan analisis penerimaan ini dilakukan dengan teknik wawancara langsung terhadap 50 responden supaya nilai error minimal. Aspek yang ditinjau dalam analisis penerimaan adalah aspek kepedulian, harga, kemasan, tekstur, kelembaban, kecukupan isi dan aroma produk. Pengolahan data dilakukan dengan skala likert dengan pembagian tiga interval penerimaan yakni rendah (1-7) sedang (8-14) dan tinggi (15-21).

\section{Kerangka Penelitian}

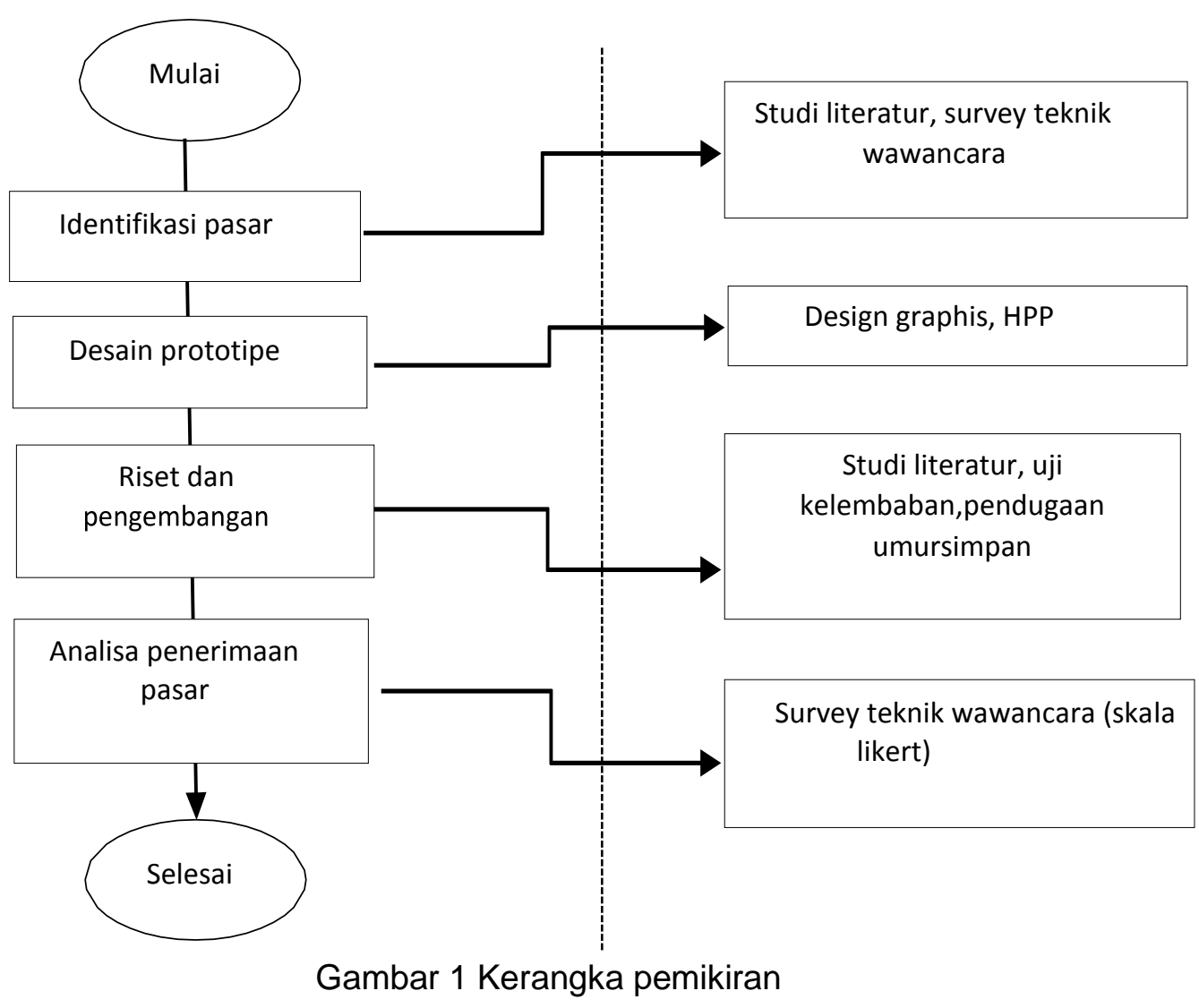




\section{HASIL DAN PEMBAHASAN}

\section{Segmen dan ukuran pasar}

Data statistik Indonesia menyebutkan jumlah penduduk usia 15-65 tahun (segmen pelanggan) pada tahun 2014 diproyeksikan sebanyak 176 juta penduduk (BPS 2013 dan Data Statistik Indonesia 2014). Jumlah masyarakat menengah ke atas (asumsi peduli kebersihan tangan) dari total penduduk sebanyak $50 \%$ adalah 88 juta merupakan total available market (TAM). PT Harlina Indah (Antis) pada tahun 2006 dalam Dwianto 2007 menganalisis market share produk handsanitizer dikuasai oleh empat (4) merek yakni antis, handy clean, dettol dan nuvo. Perkembangan dari 2006 hingga 2013 memunculkan asumsi penulis mengenai merek-merek handsanitizer lain yang beredar di masing-masing bisnis retail dan berpacu pada data yang diperoleh Dwianto (2007). Proyeksi market share pada tahun 2013 : antis (28\%), dettol (30\%), handy clean (25\%), nuvo (10\%) dan lain-lain (7\%). Served available market (SAM) sebesar 7\% atau 6,16 juta penduduk (Dwianto 2007).

Target market (TM) merupakan sasaran pasar yang dituju sebagai pasar. Berdasarkan data SAM (6,16 juta penduduk), asumsi target pasar sebesar $20 \%$ dari pasar merek lain-lain yang beredar di pasar. Angka target pasar sebesar $20 \%$ dipilih karna persaingan produk handsanitizer yang semakin ketat sehingga peluang bersaing dalam merek others kecil. Target 20\% tersebut setara dengan 1,23 juta penduduk yang tersebar di Indonesia. Ukuran pasar yang berpotensi dikembangkan untuk skala nasional sejumlah 1,23 jutapenduduk.

Ukuran pasar untuk daerah Jabotabek ditentukan dengan langkah yang sama untuk pasar nasional. Berdasarkan data yang diperoleh dari Pemerintah Jakarta (2014) jumlah penduduk kota metropolitan Jakarta mencapai 9,6 juta jiwa penduduk dan mencapai 23,6 juta penduduk wilayah Jabotabek. Bila asumsi angkatan kerja (15-65 tahun) sejumlah $75 \%$ maka besarnya sekitar 17,7 juta penduduk di Jabotabek. $50 \%$ warga merupakan ekonomi menengah ke atas, maka TAM di Jabotabek setara dengan 8,85 juta penduduk. Market share produk lain-lain adalah $7 \%$ sehingga ukuran pasar SAM sebesar 0,619 juta penduduk, dengan demikian besarnya ukuran pasar di Jabotabek adalah $20 \%$ dari 0,619 juta penduduk atau sebesar 0,123 juta penduduk sebagai pasar lokal. Langkah awal pengembangan bisnis ini dilakukan dengan pasar lokal dengan asumsi pembelian dua kali dalam satu tahun.

\section{Potensi pengembangan pelanggan}

Bersamaan dengan survey yang dilakukan di salah satu rumah makan di kawasan Jakarta Selatan diperoleh peluang pasar yang mungkin dikembangkan untuk perluasan pasar produk handsanitizer. Bisnis ini mampu menjadi salah satu rekan bisnis dalam penyedia produk preventif kesehatan mengingat rumah makan ini tergolong restoran tradisional yang memiliki lebih dari 15 outlet penjualan di seluruh Indonesia dengan omset outlet minimal per hari Rp 60.000.000.

\section{Kebiasaan masyarakat}

Data kebiasaan masyarakat berikut diperoleh berdasarkan survey tertanggal 21 Maret -22 Maret 2020 yang berlokasi di Kawasan Citra Raya, Restoran, McD, Pizza Hut. Tanggal 28 Februari hingga 2 Maret 2014 bertepatan dengan hari Jum'at hingga Minggu. Weekend dipilih karena kesediaan responden untuk mengisi kuisioner sehingga hasil penilaian diharapkan objektif. Jumlah total responden yang bersedia menjadi responden sebanyak 25 masyarakat yang berasal dari golongan usia 15-65 tahun dengan perekonomian menengah ke atas. Data yang diperoleh dalam survey tersebut selanjutnya disajikan pada gambar 2 dan 3. 


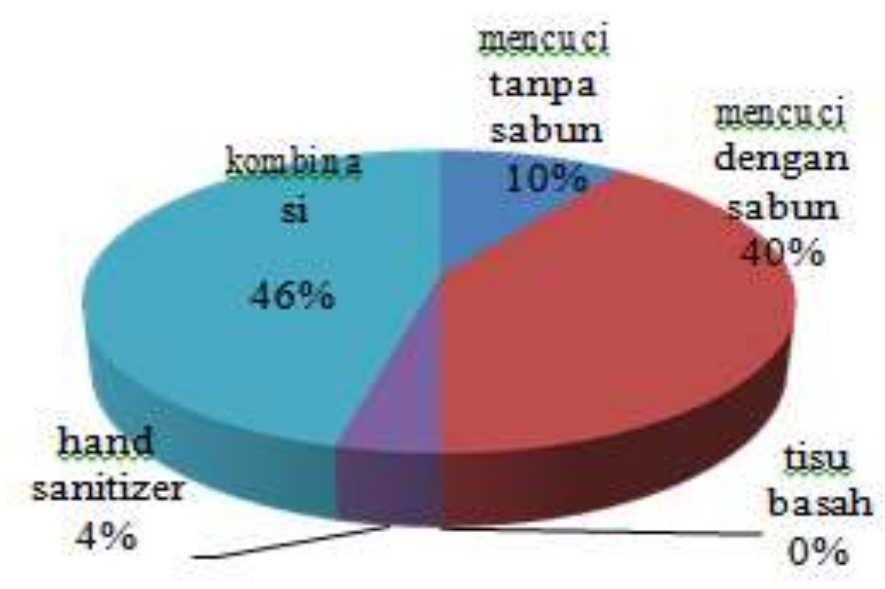

\section{Gambar 2 Cara membersihkan tangan}

Gambar 3 adalah hasil pengolahan data mengenai persentase cara umum yang dilakukan masyarakat untuk membersihkan tangan. Cara umum tersebut adalah mencuci tangan (dengan dan tanpa sabun) serta menggunakan tisu basah dan handsanitizer. Hasil yang diperoleh menunjukan cara konvensional mencuci tangan dengan sabun memiliki persen tinggi yakni $40 \%$. Mencuci dengan sabun merupakan cara utama masyarakat untuk membersihkan tangan. Gambar 3 dapat diartikan bahwa masyarakat umumnya telah peduli dengan kebersihat tangan. Kepedulian masyarakat dibuktikan dengan rendahnya persen mencuci tangan tanpa sabun (10\%) dibandingkan mencuci tangan dengan sabun.

Pembersihan tangan yang paling sering digunakan masyarakat selain dengan sabun adalah kombinasi satu cara dengan cara lainnya (46\%). Untuk penggunaan tisu basah tidak dilakukan sehari-hari, melainkan termasuk dalam cara kombinasi. Penggunaan handsanitizer dilakukan oleh 4\% masyarakat hampir di setiap waktu. Fakta yang diperoleh dari survey ini menunjukan bahwa masyarakat peduli dengan kebersihan tangan dan penggunaan handsanitizer menjadi salah satu bentuk kepedulian. Fakta lainnya adalah peluang bisnis handsanitizer terbuka karena mampu mensubstitusi mencuci tangan pada kalangan tertentu.

Wawancara juga dilakukan terhadap 25 responden tentang alasan masyarakat dalam memilih handsanitizer. Gambar 4 adalah hasil survey mengenai kebiasaan masyarakat dalam memilih produk handsanitizer. Sebagian besar masyarakat memilih produk handsanitizer berdasarkan aroma (45\%) dan kepraktisan (35\%). Masyarakat berpendapat bahwa handsanitizer yang memiliki aroma menyenangkan dan kemasan yang

Praktis akan memberi dorongan tertentu untuk meningkatkan daya beli. Alasan harga (6\%) dan kemasan (8\%) tidak menjadi alasan utama masyarakat untuk menentukan daya beli dan keinginan masyarakat dalam pemilihan handsanitizer. Hal yang harus dilakukan untuk memasuki pasar pada produk handsanitizer adalah meningkatkan kepraktisan dalam penggunaan produk dan aroma produk yang menyenangkan. Berdasarkan hasil observasi tersebut maka hal yang dapat dikembangkan adalah riset mengenai varian aroma sehingga diperoleh keunggulan produk dari segi aroma. Hal lain yang dapat dikembangkan adalah mengembangkan desain kemasan yang praktis dan disukai masyarakat. 


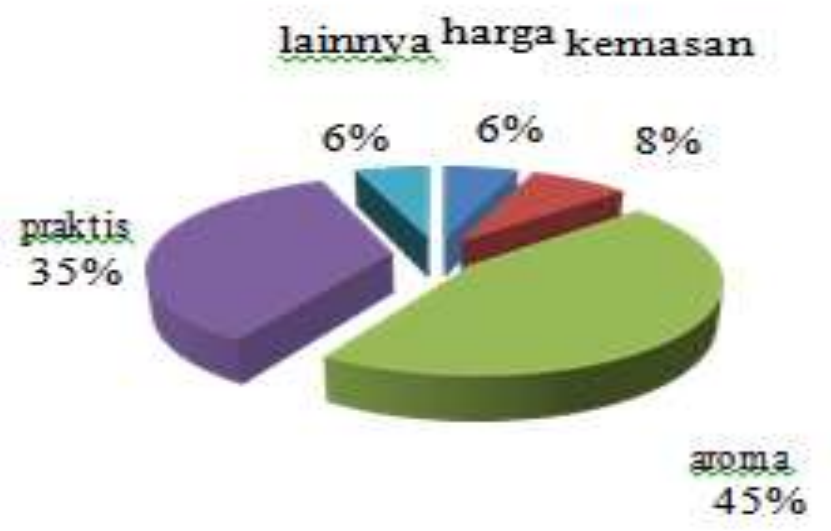

Gambar 3 Alasan memilih handsanitizer

\section{Karakteristik produk}

Produk handsanitizer yang dikembangkan merupakan hasil invensi Widyastuti pada tahun 2013. Produk yang dihasilkan tersebut merupakan produk berbahan baku alami yakni bioetanol hasil fermentasi singkong dengan aroma alami yang berasal dari minyak atsiri. Karakteristik produk memiliki pH 5,01-5,71; densitas 0,87-0,88 g/ml; viskositas $5700 \mathrm{cP}-8500 \mathrm{cP}$; serta efektifitas mikroba sekitar 16,55 CFU/. $\mathrm{cm}^{2}$ (Widyastuti 2013). Produk yang dihasilkan tersebut selanjutnya dikembangkan dalam riset bisnis dalam penelitianini.

\section{Pengujian kelembaban penggunaan produk}

Uji kelembaban tangan dilakukan untuk mengetahui pengaruh penggunaan produk terhadap penigkatan kelembaban tangan. Uji ini dilakukan kepada tujuh orang sebagai sampel menggunakan alat pembaca kelembaban skin analyzer. Pengujian kelembaban tangan ini dilakukan sebelum menggunakan handsanitizer dan setelah menggunakan handsanitizer. Selisih kelembaban tangan responden meningkat ratarata $2,143 \%$ setelah menggunakan handsanitizer (lihat Lampiran 4). Peningkatan kelembaban tangan ini merupakan hasil yang baik karena produk yang ditawarkan terbukti mampu meningkatkan nutrisi kulit pemakainya dengan meningkatnya kelembaban. Hasil uji ini merupakan inputan untuk kegiatan riset dan pengembangan produk dari aspek kelembaban.

\section{Pendugaan umur simpan}

Umur simpan merupakan salah satu kriteria mutu produk terkait ketahanan simpan produk. Menurut aturan UU nomor 18 Label tahun 2012 dan PP nomor 69 tahun 1999 dalam publikasi penelitian saudara Arif (2014) terdapat keterangan minimum label yang perlu dicantumkan salah satunya adalah tanggal kadaluarsa. Maka pendugaan umur simpan produk ini perlu dilakukan untuk memenuhi ketentuan tersebut. Penelitian mengenai pendugaan umur simpan dilakukan oleh Zetiara terhadap produk handsanitizer menggunakan metode Arrhenius. Hasil pendugaan umur simpan yakni penyimpanan pada suhu ruang selama 268,8 hari. Lama penyimpanan umur simpan ini relatif lama mengingat bahan baku produk merupakan bahan-bahan nabati seperti minyak atsiri dan etanol nabati. 


\section{Penerimaan Pelanggan}

Analisa penerimaan pelanggan dilakukan untuk mengetahui pengaruh identifikiasi pasar, desain prototipe dan kegiatan riset pengembangan terhadap penerimaan masyarakat. Prototipe hasil desain diujicoba kepada 25 masyarakat sebagai responden sesuai hasil identifikasi segmen pasar. Responden yang berusia 10-65 tahun diminta memberikan penerimaan terhadap produk yang ditawarkan (Lihat form pada Lampiran 5). Penilaian yang diberikan terhadap produk adalah skala likert berupa tiga skala yakni (1)setuju, (2)ragu-ragu dan (3)tidak setuju terhadap pernyataan.

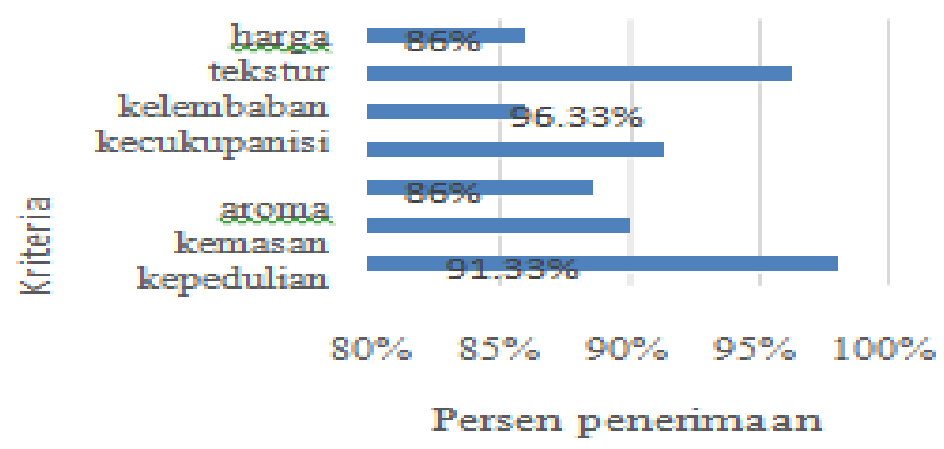

\section{Gambar 4 Persen penerimaan masyarakat}

Gambar 4 menunjukan penerimaan masyarakat pada prototipe yang dihasilkan mampu diterima baik oleh responden dengan persentase yang cukup tinggi. Penerimaan masyarakat disajikan dalam persen penerimaan masyarakat. Persen penerimaan diperoleh dari perbandingan total nilai aspek terhadap total nilai penuh (apabila penerimaan setuju dengan pernyataan). Hasil yang diperoleh untuk keseluruahan aspek mencapai 86\% sampai dengan $98 \%$ pada masing-masing aspek. Input dari hasil survey ini adalah harga yang ditawarkan untuk prototipe perlu diperbaiki, kelembaban produk perlu dikembangkan dan desain kemasan sekali pakai perlu dikaji ulang. Proses identifikasi produk, desain prototipe dan kegiatan riset terbukti mampu dijadikan model aplikasi untuk menghasilkan prototipe yang sesuai keinginan calon pelanggan.

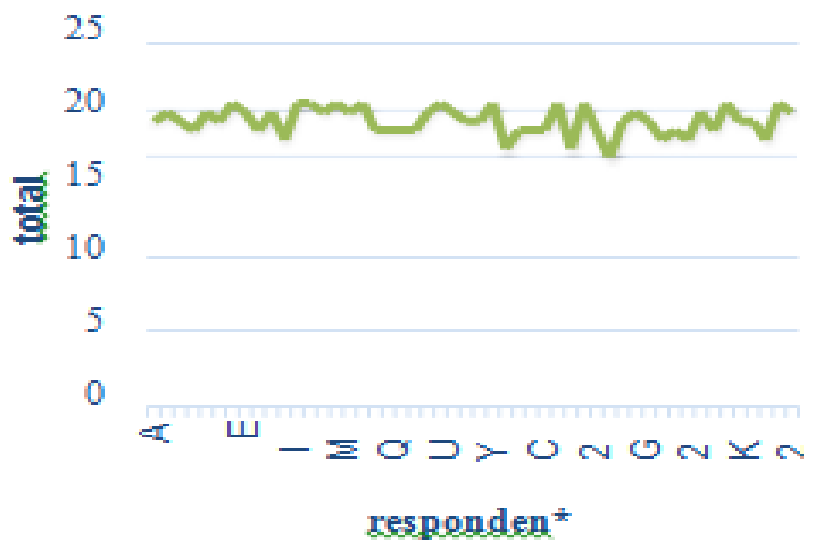

Keterangan:

(Responden*)

A hingga $T 2$

menjelaskan

nama-nama

responden

Gambar 5 Total penerimaan masyarakat 
Gambar 5 merupakan hasil lanjutan pengolahan data dari survey penerimaan masyarakat. Penyajian total penerimaan masyarakat ini bertujuan untuk mengetahui interval penerimaan responden terhadap prototipe yang ditawarkan. Pengelompokan interval ini didasarkan skala likert menjadi tiga sesuai jumlah skala yakni $1-7=$ penerimaan rendah, 8-14= penerimaan sedang, dan 15-21= penerimaan tinggi. Interval-interval tersebut diperoleh berdasarkan hasil bagi dari total selang nilai 21 (3 skala dikalikan 7 aspek). Keseluruhan nilai penerimaan responden selanjutnya diolah sedemikian sehingga diperoleh $100 \%$ responden pada interval penerimaan yang tinggi (lihat gambar 8).

Dari keselururan rangkaian tahap I pada penelitian ini diperoleh kesimpulan bahwa rangkaian proses pada tahap ini mampu menjadi evaluasi persiapan produk. Evaluasi ini mampu diaplikasikan sebagai salah satu langkah pengembangan bisnis untuk tujuan mengetahui penerimaan calon pelanggan terhadap produk yang akan ditawarkan. Rangkaian proses pada tahap I ini terbukti mampu memberikan hasil penerimaan yang tinggi oleh calon pelanggan terhadap produk yang ditawarkan.

\section{KESIMPULAN DAN SARAN}

\section{Simpulan}

Penelitian ini menghasilkan strategi pengembangan bisnis produk handsanitizer untuk tujuan peluncuran produk. Sistem yang dihasilkan adalah dua tahapan utama, tahap pertama dilakukan dengan identifikasi pasar, desain prototipe, riset \& pengembangan serta upaya validasi penerimaan calon pelanggan. Tahapan kedua dilakukan melalui tahapan identifikasi faktor-faktor, evaluasi faktor-faktor, positioning bisnis dan perumusan strategi serta analisis quantitative strategy planning matrix (QSPM). Dengan evaluasi pengembangan ini, dihasilkan desain prototipe yang mampu diterima oleh calon pelanggan dengan perimaan tinggi. Hasil yang diperoleh pada tahap dua adalah mengetahui faktor- faktor internal dan eksternal yang mempengaruhi peluncuran produk, hasil evaluasi faktor- faktor, posisi bisnis, alternatif strategi dan skenario strategi untuk peluncuruanproduk.

\section{Saran}

Melakukan strategi pengembangan pasar terlebih dahulu sebelum melakukan penetrasi pasar untuk mempersiapkan produk sebelum dilempar ke pasar. Penelitian lebih lanjut perlu dilakukan pada penerapan strategi pengembangan bisnis handsanitizer dengan marketingmix. 


\section{DAFTAR PUSTAKA}

Angkasa WI, Hubeis M, dan Pandjaitan NK. 2012. Strategi dan Kelayakan Pengembangan Lembaga Intermediasi untuk Meningkatkan Daya Saing Usaha Kecil dan Menengah di Indonesia. Jurnal Manajemen IKM, September 2012 Vol. 7 no. 2 hal95-101.

Bukhani, Z. T., \& Lesmana, R. (2020). Analisis Faktor Normatif dan Informatif Pemasaran Terhadap Keputusan Pembelian Konsumen Pada Supermarket Yogya Kota Kuningan Jawa Barat. Jurnal Pemasaran Kompetitif, 1(4).

Sutarman, A., \& Lesmana, R. (2019, January). Analisis Keputusan Pembelian Konsumen dari Sisi Normtif dan Informatif Pada Supermarket Giant Pamulang, Tangerang Selatan. In PROCEEDINGS (Vol. 1, No. 1).

Arif W. 2014. Label untuk Produk Pangan Jajanan Anak Sekolah (PJAS) untuk Pengusaha Industri Rumah Tangga (PIRT) di Kabupaten Bogor. Seminar hasil penelitian Departemen IImu dan Teknologi Pangan, siapterbit.

Assauri Sofyan. 1999. Manajemen Produksi. Edisi Revisi. Jakarta (ID). UI Press.

[BPS] Badan Pusat Statistik. 2013. Jumlah Penduduk Usia 15-65 Tahun. (Desember 2013) [Internet].(Diakses pada Desember 2013).Tersedia pada http://www.bps.go.id . Jakarta(ID).

Chatarine VA. 2012. Strategi Pengembangan Bisnis Buah Semangka pada CV Salim Abadi, Kabupaten Lampung Tengah, provinsi Lampung.[Skripsi]. Program Sarjana Ekonomi Manajemen, Departemen Agribisnis, Fakultas Ekonomi dan Manajemen. Bogor (ID) :IPB

Data Statistik Indonesia. 2014. Proyeksi Penduduk Indonesia menurut kelompok Umur dan Jenis Kelamin Tahun 2010-2015). [Internet]. (Diakses pada Januari 2014). Tersedia pada: http://www.datastatistik-Indonesia.com. Jakarta (ID).

David FR. 2010. Strategic Management - Manajemen Strategis Konsep. Edisi Keduabelas. Jakarta (ID) : Salemba Empat.

Dwianto AW. 2007. Analisis Ekuitas Merek Produk Handsanitizer Antis. [Tesis]. Program Studi Magister Bisnis, Pascasarjana. Bogor (ID): IPB

Kotler P,Amstrong G. 1997. Prinsip-Prinsip Pemasaran. Edisi Ketiga. Jilid 1. Jakarta (ID) :Erlangga.

Lesmana, R. (2019). Pengaruh Kualitas Produk Dan Kualitas Pelayanan Terhadap Kepuasan Konsumen Pt. Radekatama Piranti Nusa. Jurnal Pemasaran Kompetitif, 2(2), 115-129.

Lesmana, R. (2016). Strategi Pemasaran untuk Meningkatkan Penjualan Perumahan di Green River City Bekasi (Studi Kasus di PT. Artha Bangun Pratama). INOVASI Jurnal IImiah IImu Manajemen, 3(2), 40-59.

Lesmana, R. (2015). analisis strategi pemasaran untuk meningkatkan penjualan perumahan green river city bekasi (study kasus di pt. artha bangun pratama) (Doctoral dissertation, Universitas Pamulang).

Lesmana, R. (2019). Analisis Strategi Bersaing PT Dwi Perkasa Mobiltama Pamulang untuk Meningkatkan Penjualan. JIMF (Jurnal IImiah Manajemen Forkamma), 3(1). 
Moerdiyanto. 2008. Studi Kelayakan Bisnis. Yogyakarta (ID) : UNY Press.

Nasir, Bintoro MH, Limbong WH. 2012. Kelayakan dan Strategi Pengembangan Usaha Beras Cimanuk Melalui Peningkatan Mutu oleh PD Jaya Saputra Kecamatan Cimanuk Kabupaten Pandeglang Provinsi Banten. Jurnal Manajemen IKM, September 2012 Vol. 7 no. 2 hal 102-110.

Nainggolan TY, Sumantadinata K, Suryani A. 2010. Strategi Pengembangan Usaha "Nilla Puff " dalam Meningkatkan Pendapatan IKM Pengolahan Hasil Perikanan pada CV "X" di Cibinong Bogor. Jurnal Manajemen IKM, September 2010 Vol.5 no.2 hal132-144

Ostewalder A, Pigneur, Yves. 2010. Business Model Generation. United States of America (US) : John Willey \& sons, Inc., Hoboken, NewJersey.

Pemerintah Jakarta. 2012. Penduduk DKI Capai 9,6 Juta jiwa. [Internet]. Tersedia pada: http:/www.Jakarta.go.id/v2/news/2012/II/penduduk-dki-capai-9,6-juta-jiwa.

Rangkuti, Fredy. 2008. Analisis SWOT Teknik Membedah Kasus Bisnis. Jakarta (ID) : PT Gramedia Pustaka Utama.

Singrimbun, Masri dan Efendi, Sofyan. 1987. Metode Penelitian Survai. Jogjakarta (ID) : LP3S.

Sutrisno A, Basith A, dan Wijaya NH. 2013. Analisis Strategi Penerapan Sistem

Manajemen Keamanan Pangan HACCP (Hazard Analysis and Critical Control Points) di PT Sierad Produced Tbk. Parung. Jurnal Manajemen dan Organisasi. Vol IV (2) : 73-90.

Umar, Husein. 2000. Riset Pemasaran dan Perilaku Konsumen. Jakarta (ID) : PT GramediaPustaka.

Walpole RE. 1993. Pengantar Statistika Edisi ke-3. Jakarta (ID) : PT Gramaedia Pustaka Utama.

Widyastuti, AS. 2013. Aplikasi Minyak Atsiri pada Pembuatan Produk pembersih Tangan (Handsanitizer). [Skripsi]. Program Sarjana Teknologi Pertanian, Departemen Teknologi Industri Pertanian. Bogor (ID) : IPB

Zetiara, Alzara. 2014. Aplikasi Gel Aloevera dan Gliserin sebagai pelembab pada Produk Pembersih Tangan (Handsanitizer). [Skripsi]. Program Sarjana Teknologi Pertanian, Departemen Teknologi Industri Pertanian. Bogor (ID) : IPB. 